\title{
Management Dialectical Tension di Desa Pancasila, Kecamatan Turi, Lamongan dalam Meminimalisasi Ketegangan pada Keluarga
}

\author{
Management of Dialectical Tension in Pancasila Village, Turi \\ District, Lamongan in Minimizing Family Tension
}

\author{
Brigitta Revia Sandy Fista* \& Akhsaniyah \\ Universitas Katolik Widya Mandala Surabaya \\ Jalan Dinoyo 42-44, Surabaya, 60265 \\ *email :; gita@ukwms.ac.id;
}

Submitted: 10-05-2021, Revised: 21-06-2021, Accepted: 06-07-2021, Published: 19-07-2021

Doi: https://doi.org/10.33508/jk.v10i1.3145

\begin{abstract}
This study focuses on the dialectical tension management strategy for married couples of different religions in Pancasila Village, Turi District, Balun, Lamongan. Balun Village was chosen because it has a high level of religious tolerance. Using the Rational Dialectical theoretical perspective, this study reveals how individuals feel in communicating, identifies the causes of tension in communication, and communication strategies in overcoming tensions in interfaith families. This study uses a qualitativedescriptive approach with a case study method, intending to be able to describe in detail how the tensions formed in interfaith families in Balun Village are minimized. Data collection techniques were carried out by in-depth interviews and observations, to obtain a complete picture of their daily communication practices. The results of this study indicate that there are different dialectical tension management patterns, which are based on the level of tension that arises and the issues that trigger tension. The main cause of tension in interfaith family communication is related to two things; lack of openness of the parties and the influence of stereotypes on different ethnicities in the family.
\end{abstract}

Keywords : Management Dialectical Tesion, Tolerance, Family.

\begin{abstract}
ABSTRAK
Penelitian ini difokuskan pada strategi management dialectical tension pada pasangan suami-istri berbeda agama di Desa Pancasila, Kecamatan Turi, Balun, Lamongan. Desa Balun dipilih karena memiliki tingkat toleransi keberagamaan yang tinggi. Dengan menggunakan perspektif teoritis Rational Dialectical penelitian ini mengungkapkan bagaimana perasaan individu dalam berkomunikasi, identifikasi penyebab ketegangan dalam komunikasi, serta strategi komunikasi dalam mengatasi ketegangan pada keluarga beda agama. Penelitian ini menggunakan pendekatan kualitatif-deskriptif dengan metode studi kasus, dengan tujuan agar dapat menggambarkan secara detail bagaimana ketegangan yang terbentuk dalam keluarga beda agama di Desa Balun diminimalkan. Teknik pengumpulan data dilakukan dengan wawancara mendalam dan observasi, agar memperoleh gambaran utuh atas praktek komunikasi keseharian yang mereka lakukan. Hasil penelitian ini menunjukkan adanya pola management dialectical tension yang berbeda, yang berbasis pada level ketegangan yang muncul dan isu yang memicu ketegangan. Penyebab utama munculnya ketegangan dalam komunikasi keluarga beda agama berkaitan dengan dua hal; kurangnya keterbukaan para pihak serta pengaruh stereotype atas etnis yang berbeda dalam keluarga.
\end{abstract}

Kata kunci: Management Dialectical Tension, Toleransi, Keluarga 


\section{Latar Belakang}

Pluralisme menjadi sebuah wacana yang berkembang di tengah kaum posmodernis, dengan mengagungkan keberagaman dan menolak penyeragaman. Pengakuan terhadap pluralitas adalah suatu hal yang dibutuhkan dalam masyarakat yang mempunyai keragaman budaya yang tinggi, yaitu dengan mengurangi sekat-sekat dan batas budaya. Kata kunci yang dapat menjelaskan makna pengakuan pluralitas adalah batas dan asing. Pengakuan pluralitas ini merupakan kajian dari komunikasi multicultural (Purwasito, 2015: 188). Untuk memenuhi kebutuhan dan tujuan hidupnya, manusia membutuhkan orang lain. Dalam masyarakat multikultur akan mengalami berbagai jenis hambatan, antara lain hambatan budaya, seperti hambatan rasial, agama, etnis, kelas, bahkan hambatan gender.

Herskovits (dalam Purwasito, 2015) menyebutkan bahwa terdapat empat unsur dalam kebudayaan, antara lain keluarga, alat-alat teknologi, system ekonomi, kekuatan politik. Dalam kajian ini keluarga merupakan menjadi focus utama, lebih tepatnya adalah bagaimana komunikasi antar budaya terjadi pada sebuah keluarga. Komunikasi antara budaya merupakan komunikasi antar pribadi yang dilakukan oleh mereka yang berbeda latar belakang kebudayaan (Liliweri, 2004).

Liliweri (2004) mengatakan definisi yang paling sederhana dari komunikasi antar budaya adalah komunikasi antarpribadi yang dilakukan oleh mereka yang berbeda latar belakang kebudayaan. Sedangkan untuk mencapai komunikasi antar budaya yang efektif, maka seseorang wajib memiliki kompetensi komunikasi antar budaya yang mumpuni. Pada era globalisasi, komunikasi antar budaya sangat sering digunakan dan merupakan kegiatan berkomunikasi yang tidak dapat terelakkan. Tak hanya di bidang ekonomi, teknologi tetapi juga dalam hal politik dan kebudayaan. Dengan perkembangan teknologi yang semakin cepat membuat manusia dengan sangat mudah dapat melakukan komunikasi antar budaya. Dalam proses komunikasi antar budaya sendiri, antara komunikator dan komunikan berasal dari latar belakang kebudayaan yang berbeda. Dan karena inilah yang membuat manusia menjadi makhluk yang istimewa dimana manusia memiliki sifat, kepribadian dan perilaku yang unik.

Komunikasi antar budaya merupakan komunikasi yang terjadi antara orangorang yang memiliki kebudayaan yang berbeda (ras, etnik, agama, atau sosio ekonomi) (Sihabudin, 2013). DeVito (1997) menyatakan bahwa budaya juga merupakan segala hal yang dihasilkan dan dikembangkan oleh anggota kelompok tertentu misalnya bahasa, cara berpikir, seni, undang-undang dan agama. DeVito (1997) juga menegaskan bahwa kultur dapat didefinisikan sebagai gaya hidup yang relatif khusus dan suatu kelompok masyarakat yang terdiri atas nilai-nilai, kepercayaan, artefak, cara berperilaku, serta cara berkomunikasi yang ditularkan dari satu generasi ke generasi lainnya.

Komunikasi dilakukan oleh orangorang yang memiliki budaya yang berbeda (dalam hal ini berbeda bangsa, agama, tas, Bahasa, status social dan lainnya dapat dikatakan sebagai komunikasi antar budaya. Aktivitas komunikasi sangat berguna dalam kehidupan sehari-hari sehingga sangat diperlukan dalam menjalin hubungan dengan orang lain, tanpa adanya komunikasi yang efektif akan menimbulkan sebuah tension yang akan menyebabkan keretakan dalan sebuah hubungan. Dikatakan komunikasi yang 
efektif ketika apa yang disampaikan sama dengan apa yang ditangkap atau dimaknai oleh lawan bicaranya. Apabila tidak sesuai, bisa saja ketegangan/tension yang biasa dikenal dengan salah paham atau salah pengertian.

\section{Ketegangan/tension merupakan} sebuah situasi perselisihan atau adanya tension yang muncul diantara dua pihak atau lebih. Ketegangan / tension sendiri dapat terjadi pada antar pribadi, kelompok, dan organisasi. Sehingga dapat dikatakan bahwa selama ada komunikasi pasti akan mengalami tension jika komunikasi tersebut tidak berjalan efektif.

Situasi seperti ini terjadi pada Desa Balun yang memiliki sikap toleransi yang tinggi, meskipun ada beragam agama dan budaya. Dengan sebutan khusus yaitu Desa Pancasila, di desa tersebut dapat dilihat bagaimana seharusnya masyarakat yang beragam berinteraksi dengan sesama. Toleransi sangat diperlukan dalam menjaga kerukunan umat beragama, seperti diketahui bahwa Indonesia memiliki beragam agama, Islam, Kristen, Katolik, Hindu, Budha dan Konghuchu. Dengan adanya keragaman agama tersebut sangat rawan adanya intoleransi yang berujung konflik di masyarakat. Kasus yang baru saja terjadi karena ketidaknyamanan masyarakat terhadap pengeras suara (toa masjid), maka terjadi konflik yang berujung bui. Seperti yang diberitakan Kompas.com 21 Agustus 2018, Meilliana dari Medan Sumatra Utara divonis 18 bulan atau 1,5 tahun penjara, karena terbukti melanggar pasal 156 KUHP yaitu melakukan penghinaan terhadap suatu golongan di Indonesia terkait ras, negeri asal, agama, tempat asal, keturunan, kebangsaan atau kedudukan menurut tata hukum negara.

Kasus Meilliana kemungkinan tidak akan terjadi jika ada pada masyarakat yang memiliki toleransi dalam beragama.
Pengeras suara masjid tidak akan menjadi persoalan jika sebelumnya sudah ada kesepakatan bersama tentang bagaimana cara penggunaannya, dengan mengutamakan kenyamanan bersama. Terbukti di desa Balun, rembuk desa yang digagas oleh aparatur desa dalam hal ini kepala desa dan jajarannya, bersama-sama dengan masyarakat dan tokoh agama, seringkali membahas mengenai penggunaan pengeras suara (toa masjid) dan penggunaan peralatan tempat ibadah lainnya. Tidak hanya sebatas penggunaan peralatan tapi juga tentang ritual keagamaan apa saja yang diperlukan untuk dibicarakan bersama. Menurut kepala Desa Balun (Khusyairi), hal semacam ini perlu dilakukan untuk menghindari kasak kusuk masyarakat akan ketidaknyamanan dalam kesehariannya, jika ada ritual keagamaan yang dirasa mengganggu. Dari ketidaknyamanan tersebut biasanya akan berujung konflik di masyarakat, maka rembuk desa ini lah sebagai wadah untuk menuangkan segala keluhan dan diusahakan untuk mendapatkan solusi bersama.

Desa Balun termasuk memiliki keragaman dan aktivitas budaya yang cukup tinggi, karena terdapat tiga agama yaitu Islam, Kristen dan Hindu. Uniknya adalah lokasi tempat peribadatannya cukup berdekatan, dalam satu kompleks, yaitu Masjid Miftahul Huda, Gereja Kristen Jawi Wetan (GKJW), serta Pura Sweta Maha Suci. Berdasarkan wawancara dengan Khusyairi, Desa Balun yang terdiri atas 10 RT memiliki sekitar 4.600 warga, dengan 75 persen diantaranya memeluk agama Islam, 18 persen beragama Kristen, dan sisanya beragama Hindu. Sebagian besar mata pencaharian warga adalah petani dan petambak. Selain itu, menurut Kepala Desa Balun, mereka memberikan fasilitas tempat di Balai Desa untuk membuat kerajinan tangan berupa lampu 
lampion dan mebel. Kerajinan tangan ini dikerjakan oleh masyarakat sekitar yang diprakarsai oleh karang taruna. Mereka membutuhkan penghasilan lain, jika musim kemarau tiba, karena tambak ikan dan udang tidak membuahkan hasil. Sampai saat ini hasil dari kerajinan ini masih bisa mencukupi kebutuhan sehari-hari masyarakat Balun.

Dengan adanya keragaman agama di Desa Balun, apalagi dengan adanya tempat ibadah yang berdekatan, maka besar kemungkinannya untuk terjadi gesekan akan kepentingan masingmasing. Namun pada kenyataannya di desa ini hampir dipastikan tidak pernah terjadi gesekan yang berujung konflik. Masyarakatnya baik Islam, Kristen dan Hindu bisa hidup berdampingan. Seperti yang sudah diuraikan sebelumnya, bahwa ada rembuk desa yang diprakarsai oleh aparatur desa, ternyata hal ini sangat efektif karena bisa memberikan masukan dan mendiskusikan segala masalah yang terjadi di masyarakat. Tidak hanya rembuk desa namun acara-acara hajatan warga bisa dijadikan sebagai wadah untuk melakukan kordinasi antara aparatur desa, tokoh agama dan masyarakat. Menurut pengakuan kepala desa, seringkali hajatan warga diikuti sampai larut malam bahkan sampai pagi untuk membicarakan hal-hal yang sedang hangat dibicarakan.

Toleransi beragama di Desa Balun bisa tampak salah satunya dari cara memperingati hari besar keagamaan. Dalam Forum Dialog Bersama yang dilakukan Mahasiswa mata kuliah Komunikasi dan Multikultural, Fikom Widya Mandala bersama tokoh agama dan aparatur desa di Desa Balun, Adi Wiyono sebagai perwakilan tokoh umat Hindu menyebutkan, bahwa pada perayaan hari raya Nyepi tidak pernah terjadi masalah, karena warga selain Hindu juga ikut menghormati ritual yang dilakukan umat
Hindu. Pada hari Nyepi, umat Islam tidak menggunakan toa atau pengeras suara masjid yang besar, karena untuk menghormati umat Hindu yang sedang melakukan ibadah Nyepi. Pernyataan ini didukung oleh Sumitro, tokoh perwakilan dari umat Islam, bahwa pada perayaan hari Nyepi Takmir Masjid sudah pasti akan mematikan pengeras suara sampai peringatan Nyepi selesai. Oleh karena itu, penelitian ini akan mengungkapkan strategi apa yang dilakukan oleh keluarga berbeda agama di Desa Balun dalam meminimalkan ketegangan terkait perbedaan agama.

Setiap individu mempunyai kebutuhan untuk mengungkapkan sesuatu kepada orang lain, yang kita kenal disebut perasaan. Perasaan merupakan reaksi internal kita terhadap aneka pengalaman kita (Supratiknya, 1995 : 50). Menurut Supratiknya, ada dua cara untuk mengungkapkan perasaan yaitu secara verbal dan non verbal. Secara verbal adalah dengan menggunakan kata-kata, baik secara langsung mendeskripsikan perasaan yang kita alami maupun tidak. Sedangkan yang dimaksud secara nonverbal adalah dengan menggunakan isyarat lain selain kata-kata, misalnya sorot mata, raut muka, kepalan tinju, dan sebagainya (Supratiknya, 1995).

Menurut Johnson dalam buku Komunikasi Antarpribadi : Tinjauan Psikologis milik Supratiknya (1995), ada 8 cara mengungkapkan perasaan secara verbal : (1) Mencap atau memberikan label. Misal, kita tidak senang pada seorang teman yang suka menyela pembicaraan orang; (2) Memerintah. Misal, kita merasa tersinggung oleh komentar yang diberikan oleh seorang teman; (3) Bertanya. Perasaan tersinggung yang disebut pada nomor 2 diatas juga dapat diungkapkan dalam bentuk pertanyaan; (4) Menuduh. Misal, kita sangat kecewa tidak berhasil 
menemukan benda yang sedang sangt kita butuhkan. Untuk mengungkapkannya, kita menuduh teman sekamar kita, "Kau yang mengambil dan menyembunyikannya, ya"; (5) Menyindir (sarkasme); (6) Memuji; (7) Mencela; (8) Memberikan sebutan. Misal, para mahasiswa menyebut seorang dosennya "killer", untuk mengungkapkan rasa kesal mereka karena berkali-kali gagal menempuh ujian mata kuliah yang diampu oleh dosen tersebut. (Supratiknya, 1995).

$$
\text { Sedangkan dalam }
$$

mengungkapkan perasaan secara nonverbal lebih kepada ekspresi wajah, jeda atau tenggang waktu dalam berbicara, gerak tangan, jarak, kontak mata, sikap tubuh, cara berpakaian, volume suara, dan intonasi, sentuhan atau rabaan, cara mengatur kamar, dan sebagainya, semuanya itu adalah perbuatan dan sekaligus merupakan modalitas komunikasi nonverbal (Supratiknya, 1995).

Selain perayaan Hari Raya Nyepi, toleransi juga terjadi pada saat perayaan Hari Raya Natal, selain menghormati, umat Islam dan Hindu juga ikut meramaikan suasana Natal. Mereka ikut membantu menghias pohon Natal yang ada di gereja dengan ornamen yang menarik, juga ikut membantu pementasan opera pada malam Natal. Hal tersebut disampaikan oleh Sutrisno sebagai perwakilan tokoh umat Kristen, dalam Forum Dialog Bersama yang dilakukan mahasiswa mata kuliah komunikasi dan multikultural, Fikom Widya Mandala Surabaya bersama masyarakat Desa Balun.

Dengan beragamnya agama dan budaya di Desa Balun ini, juga sikap toleransi yang tinggi terhadap perbedaan agama, maka tidak bisa dihindari juga tentang pernikahan beda agama. Fenomena pernikahan beda agama selalu ada dalam masyarakat yang beragam seperti di Indonesia, yang sangat identik dengan konflik karena untuk menyatukan perbedaan dalam berumah tangga tidak mudah. Terlebih lagi, menurut diskusi pakar hukum (hukum.com), dalam hukum perkawinan di Indonesia tidak memberikan ruang dan peraturan khusus pada perkawinan beda agama. Mengenai sahnya perkawinan adalah perkawinan yang dilakukan sesuai agama dan kepercayaannya sebagaimana diatur dalam UU No 1 Tahun 1974 tentang Perkawinan, Pasal 2 ayat (1). Hal ini berarti UU Perkawinan menyerahkan pada ajaran dari agama masing-masing. Namun, permasalahannya apakah agama yang dianut oleh masing-masing pihak tersebut membolehkan untuk dilakukannya perkawinan beda agama. Misalnya, dalam ajaran Islam perempuan tidak boleh menikah dengan laki-laki yang tidak beragama Islam (Al Baqarah [2]: 221). Selain itu, juga dalam ajaran Kristen perkawinan beda agama dilarang (II Korintus 6: 14-18).

Hubungan romantis tidak hanya melibatkan dua orang yang saling berhubungan, tetapi juga melibatkan pihak luar yang dapat mempengaruhi hubungan romantis. Pacaran beda agama adalah hubungan romantis antara individu yang berbeda agama. Perbedaan budaya dan sistem budaya terlihat dari adanya perbedaan baik dari agama, suku, ras, dan bahasa. Namun ketika perbedaan itu menyangkut sebuah agama maka menjadi hal yang sangat sensitif, apalagi jika perbedaan tersebut dilibatkan dalam hubungan romantic dalam penelitian ini khususnya pasangan suami-istri. Sekarang ini, perbedaan agama menjadi fenomena yang sangat menarik. Tidak hanya dalam kehidupan sehari, di internet dan media pun telah mengangkat persoalanpersoalan akan adanya perbedaan agama yang saat ini telah menjadi konsumsi umum. 
Menarik untuk diteliti, apakah memang benar di dalam keluarga pasangan yang berbeda agama di Desa Balun ini tidak pernah terjadi konflik, atau ketegangan. Terlebih dalam mengambil suatu keputusan keluarga atau hal kecil dalam kesehariannya. Asumsinya dalam lingkungan yang sangat toleran, dimana hubungan antar warga terjaga dengan baik meskipun mereka berbeda, maka akan tercipta juga hubungan yang toleran dalam anggota keluarga yang berbeda agama. Namun apakah asumsi ini benar, karena hubungan antar pribadi akan lebih rumit dibandingkan dengan hubungan yang lebih makro, dalam hal ini hubungan dengan kelompok yang lebih besar.

Penelitian tentang dialectic tension ini lebih menarik karena tidak hanya melihat pada interactional dialectics seperti pada umumnya yang hanya melihat ketegangan dari pasangan romantis itu sendiri, tetapi juga melihat contextual dialectics dengan melihat lingkungan sekitar yang dapat mempengaruhi hubungan romantis. Contextual Dialectics dalam hal ini adalah lingkungan keluarga pasangan romantic. Selain melihat ketegangan yang muncul pada pasangan romantis beda agama, dan antara pasangan romantis beda agama dan orang tuanya, penelitian ini juga ingin melihat strategi yang digunakan untuk meminimalisir ketegangan.

Dialektikal Kontekstual (contextual dialectics) dibentuk melalui keteganganketegangan yang muncul dari tempat hubungan tersebut berada dalam suatu budaya. William Rawlins menyebutkan ada dua dialektikal kontekstual, yaitu yang pertama adalah Public and Privat Dialectics. Pengertian dari public dan privat dialectics yaitu dialektikal kontekstual muncul dari ketegangan antara hubungan pribadi dan kehidupan publik (West \& Turner, 2009). Yang kedua adalah Real and Ideal
Dialectics, pengertiannya yaitu dialektikal kontekstual yang muncul dari perbedaan antara hubungan yang dianggap ideal dengan hubungan yang sedang dijalani (West \& Turner, 2009).

Dialektika Publik dan privat; Dialektika kontekstual yang muncul dari hubungan privat kehidupan publik. Rawlins menyatakan bahwa dialektik menyebabkan munculnya suatu hal dalam persahabatan yang disebutnya sebagai agen ganda. Maksudnya hubunganhubungan ini memenuhi baik fungsi publik, maupun fungsi privat. contohnya orangorang yang membentuk persahabatan di tempat kerja mungkin akan menghadapi umpan balik yang negative dari orangorang yang ada disekeliling mereka, yang melihat bahwa persahabatan ini merupakan ancaman bagi mereka.

Dialektika yang nyata dan yang ideal; Dialektika kontekstual yang muncul dari perbedaan antara hubungan yang ideal dengan hubungan yang sedang dijalani. Dialektik ini menunjukan kontradiksi akan semua harapanyang dimiliki sesorang mengenai hubungan dengan kenyataan yang sedang di jalani. Secara umum, harapan mengenai hubungan biasanya memiliki standar yang tinggi dan ideal. Sedangkan Dialektikal Interaksional (interactional dialectics) dibentuk melalui ketegangan-ketegangan yang muncul dari dalam hubungan romantis itu sendiri dan dibangun oleh komunikasi. Menurut Baxter ada tiga hal paling relevan dalam hubungan, yaitu (1) autonomy and connection; (2) openness and protection; dan (3) novelty and predictability (West\&Turner, 2009:238-241). Otonomi dan keterikatan, merujuk pada keinginan-keinginan pasangan yang selalu muncul untuk menjadi tidak tergantung pada orangorang terdekatnya, dan juga untuk menemukan keintiman dengan mereka. 
Keterbukaan dan perlindungan berfokus pada kebutuhan-kebutuhan pasangan untuk terbuka, membuka semua informasi pribadi pada pasangan mereka. Selain itu juga untuk bertindak strategis dan melindungi diri sendiri dalam komunikasi pasangan romantis. Hal yang baru dan tidak dapat diprediksi berhubungan dengan permasalahan antara kenyamanan dari keseimbangan hubungan dan kegembiraan dengan adanya perubahan. Dengan adanya keteganganketegangan tersebut baik contextual dialectics maupun interactional dialectics, maka harus segera dicari strategi yang cocok agar tidak merusak hubungan. Untuk mengatur dan meminimalisir agar ketegangan tidak merusak hubungan baik itu hubungan antara orang tua dan anak ataupun hubungan romantis, maka perlu ada strategi untuk me-manajemen ketegangan. Inilah yang akan dilihat dalam penelitian ini, dengan lebih dulu mengkategorikan ketegangan yang terjadi dalam pasangan suami-istri di Desa Pancasilan kemudian peneliti akan menganalisis strategi apa yang mereka gunakan untuk mengatur dan meminimalisir ketegangan tersebut.

Dari penjelasan di atas, maka peneliti ingin meneliti tentang bagaimana Strategi Management Dialectical Tension Pasangan Suami-Istri Berbeda Agama di Desa Pancasila, Kecamatan Turi, Lamongan dalam Meminimalkan Ketegangan pada Keluarga. Menurut Baxter (1988) dalam buku Introducing Communication Theory : Analysis and Application milik Richard West dan Lynn $\mathrm{H}$. Turner, dalam manajemen dialectical tension, ada beberapa strategi yang dapat digunakan untuk mengatur dan meminimalisir tension, yaitu : (1) Cyclic alternation - respons untuk menghadapi ketegangan dialektis; merujuk pada perubahan sejalan dengan waktu dan terus berputar; (2) Segmentation - tanggapan dialectical yang berhubungan dengan perubahan hak dalam konteks; (3) Selection - berhubungan dengan pembuatan keputusan diantara pertentangan; (4) Integration - terdiri dari tiga strategi yaitu menetralisasi, membingkai ulang dan mendiskualifikasi (West \& Turner, 2009: 244-246).

Beberapa strategi yang ada, diharapkan dapat meminimalisir tension yang terjadi pada suatu hubungan. Dengan adanya strategi yang dapat meminimalisir tension, hubungan interpersonal yang terjadi dapat terjalin dengan baik dan cenderung lebih baik lagi. Cukup banyak kajian penelitian tentang keragaman budaya di Balun dengan sudut pandang berbagai disiplin ilmu, antara lain adalah; Damayanti (2020), Ulum (2019), Azizah dkk (2020), Anggorowati dan Sarmini (2015), Rozi dan Utomo (2019), dll. Dari beberapa kajian penelitian yang ada terdapat perbedaan tentang pemaknaan, objek, subjek dan metode yang digunakannya. Pengangkatan fenomena yang berbeda dengan berbagai macam sudut pandang menjadikan pengayaan dalam melihat wilayah Balun dengan berbagai keragamannya yang bisa dilihat dari banyak aspek. Penelitian ini mengambil sudut pandang yang berbeda dari penelitian lainnya yaitu mengambil subjek informan yang relative kecil yaitu komunikasi interpersonal dalam keluarga dengan latar belakang budaya yang berbeda.

\section{Metode}

Studi kasus tepat digunakan untuk pertanyaan suatu penelitian berkenaan dengan "how" atau "why", bila penelitian hanya memiliki sedikit peluang untuk mengontrol peristiwa - peristiwa yang akan diselidiki, dan bilamana fokus 
penelitiannya terletak pada fenomena kontemporer (masa kini) di dalam konteks kehidupan nyata. Selain itu, penelitian studi kasus dapat dibedakan menjadi tiga tipe, yaitu studi kasus eksplanatoris, eksploratoris dan deskriptif (Yin, $2000: 1$ ).

Pendapat serupa di sampaikan oleh Sarwono, studi kasus merupakan suatu metode untuk menyelidiki atau mempelajari suatu kejadian mengenai perseorangan (riwayat hidup). Pada metode studi kasus ini diperlukan banyak informasi guna mendapatkan bahan-bahan yang agak luas. Metode ini merupakan integrasi dari data yang diperoleh dengan metode lain (Sarwono, 2006 : 55).

Penelitian ini menggunakan teknik pengumpulan data dengan depth interview. Wawancara sebagai instrument utama dalam pengumpulan data dalam penelitian ini. Wawancara merupakan proses memperoleh keterangan untuk tujuan penelitian dengan cara tanya jawab sambil bertatap muka antara pewawancara dengan responden menggunakan alat yang dinamakan guideline interview. Wawancara yang dilakukan ditujukan kepada informan dinilai peneliti memiliki kriteria yang mewakili sebagai narasumber, yaitu pasangan suami-istri di Desa Balun, Kecamatan Turi, Lamongan yang pernah mengalami tension terkait perbedaan keluarga dalam keluarga

Penerapannya pada penelitian ini, maka dapat dideskripsikan bagaimana Strategi Management Dialectical Tension Pasangan Suami-Istri Berbeda Agama di Desa Pancasila, Kecamatan Turi, Lamongan dalam Meminimalkan Ketegangan pada Keluarga. Yin membagi penelitian studi kasus secara umum menjadi 2 (dua) jenis, yaitu penelitian studi kasus dengan menggunakan kasus tunggal dan jamak/banyak. Penelitian ini menggunakan studi kasus tunggal karena berfokus pada
Strategi Management Dialectical Tension Pasangan Suami-Istri Berbeda Agama di Desa Pancasila, Kecamatan Turi, Lamongan dalam Meminimalkan Ketegangan pada Keluarga. (Yin, 2000 : 44).

Wawancara dilakukan kepada informan dinilai memiliki kriteria yang mewakili sebagai narasumber, yaitu pasangan suami-istri di Desa Balun, Kecamatan Turi, Lamongan yang pernah mengalami tension terkait perbedaan keluarga dalam keluarga. Profil informan yang ditemui dapat dijabarkan sebagai berikut :

1. Bambang : Seorang etnis Jawa, dan beragama Hindu. Bambang yang lahir di Surabaya pada tahun 1975 ini telah tinggal di Desa Balun mulai dari usia 13 tahun sejak ikut pindah bersama Ayah dan Ibunya. Sebagai seorang Hindu, Bambang memiliki ketertarikan untuk menjadi seniman khususnya seni yang berkaitan dengan kesenian Hindu. Pada saat usia 13 tahun tersebut, dia sudah mulai ada ketertarikannya dalam seni musik gamelan Hindu. Saat masih muda dia tidak hanya belajar bermain musik saga saja tetapi juga aktif dalam kegiatan keagamaan di Pura. Hingga menjadi pelatih sampai sekarang, Bambang pun tetap menjadi anggota pemain music dalam kelompok pemain musik di Pura. Dia sangat aktif terutama jika ada perayaan Ogoh-Ogoh di desanya. Di lingkungan tempat tinggalnya, Bambang juga aktif menjadi pengurus di desa.

2. Nurkiati : Istri Bambang (dipanggil Yati), yang lahir dari keluarga beretnis Jawa dan beragama Kristen. Bambang dan Yati menikah secara Kristen, hal ini dilakukan karena ada kesepakatan oleh keluarga besar agar Bambang dan Yati tetap dapat melaksanakan pernikahan. Akan tetapi dalam 
kehidupan sehari-harinya, Bambang dan Yati tetap menjalankan agama mereka masing-masing (Bambang beragama Hindu dan Yati beragama Kristen). Kesepakatan-kesepakatan seperti ini dikatakan sering terjadi dalam keluarga mereka, hal ini dilakukan demi menjalankan yang namanya kompromi pada sebuah permasalahan dan tidak membesarbesarkan masalah yang sudah ada.

3. Helmi : Seorang etnis Madura dan memeluk agama Islam. Helmi lahir di Surabaya pada tahun 1997. Perawakannya yang tinggi membuatnya dipilih sebagai bidang keamanan dan ketertiban desa. Helmi beretnis Madura akan tetapi ia lahir dan besar di Desa Balun Lamongan. Karena lahir dan besar di Desa Balun, Helmi paham betul bagaimana masyarakat Desa Balun memiliki pandangan mengenai keragaman etnis dan agama yang ada disekitar mereka.

4. Kiki : Istri Helmi yang beretnis Jawa. Kiki lahir dan besar sebagai orang Jawa yang beragam Kristen. Akan tetapi keluarga besar Kiki memiliki latar belakang yang beragam. Ibu dari Kiki merupakan orang Tionghoa Kristen, sedangkan Ayah berlatar belakang etnis Jawa dan beragam Kristen. Kondisi keluarga Kiki penuh dengan keragaman etnis dan agama, yang tidak dapat dipungkiri pasti ada saja ketegangan yang terjadi dalam keluarga besar mereka karena adanya perbedaan cara berpikir terkait suatu hal. Tidak hanya ketika berpendapat tetapi juga bagaimana mereka berpakaian dan berkata-kata seringkali tidak dapat terhindar dari yang namanya ketegangan.
Adapula alasan pemilihan kriteria diatas adalah sebagai berikut :

1. Pasangan suami-istri berdasarkan alasan bahwa kajian atau pokok bahasan dalam penelitian ini berfokus pada interaksi dan komunikasi yang terjadi antar personal atau secara khusus dalam penelitian ini ada di dalam relasi pasangan menikah (committed romantic relationship) yang mana dalam relasi pasangan yang sudah menikah diduga memiliki keunikan cara komunikasi dan ketegangan/tension yang unik yang terjadi. Oleh karena itu, kriteria bahwa pasangan suami-istri menjadi subyek dalam penelitian ini menjadi penting.

2. Pasangan suami - istri di Desa Pancasila, Kecamatan Turi, Lamongan lokasi Desa Pancasila, Kecamatan Turi, Lamongan dipilih karena memiliki keragaman dan aktivitas budaya yang cukup tinggi, karena terdapat tiga agama yaitu Islam, Kristen dan Hindu. Uniknya adalah lokasi tempat peribadatannya cukup berdekatan, dalam satu kompleks. Dengan beragamnya agama dan budaya di Desa Balun (Desa Pancasila) ini, juga sikap toleransi yang tinggi terhadap perbedaan agama, maka tidak bisa dihindari juga tentang pernikahan beda agama. Hal ini yang menjadi alasan peneliti tertarik untuk melakukan penelitian di Desan Balun.

3. Pernah mengalami tension terkait perbedaan agama dalam keluarga $\rightarrow$ berdasarkan alasan bahwa pokok bahasan dalam penelitian ini terkait strategi meminimalkan ketegangan/tension. Maka subyek yang akan diteliti hendaknya pernah mengalami sebuah ketegangan/tension dalam hubungan pernikahannya.

\section{Hasil dan Pembahasan}

Hasil dari penelitian ini akan terbagi dalam beberapa hal. Pertama akan diuraikan terlebih dulu terkait 
ketegangan/tension yang terjadi antar pasangan suami-istri, lalu kedua akan dijelaskan dan diuraikan terkait strategi yang dilakukan oleh pasangan suami istri untuk meminimalkan ketegangan.

1. Tension pada Pasangan Suami-Istri Berbeda Agama di Desa Pancasila, Kecamatan Turi, Lamongan

Saat individu melakukan komunikasi antar budaya, tidak dapat dihindari pasti ada permasalahanpermalahan yang menyebabkan munculnya ketegangan-ketegangan. Ketegangan-ketegangan yang dialami membuat komunikasi yang dilakukan tidak efektif. Komunikasi dengan seseorang yang memiliki kebudayaan yang berbeda akan membuat perbedaan juga dalam beberapa hal. Juga didukung dari latar belakang keluarga individu tersebut, bagaimana mereka dididik dari kecil.

Berdasarkan hasil wawancara dan observasi yang penulis dapatkan, ada beberapa penyebab yang dapat menimbulkan ketegangan. Seperti pada kasus Bambang yang menimbulkan ketegangan diantara Bambang dan istrinya adalah :

\section{Bagan IV.1. Bagan ketegangan yang terjadi pada pasangan suami istri Bambang dan Yati}

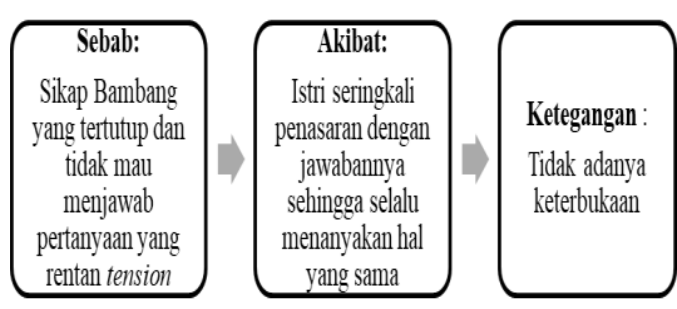

Sumber : Olahan Peneliti

Bagan diatas menunjukkan ketegangan yang terjadi antara Bambang dengan istrinya. Ketegangan yang terjadi disebabkan oleh sikap Bambang yang tertutup tentang diri dan keluarganya dan sikap Bambang yang tidak mau menjawab jika ada pertanyaan dari istrinya apabila ada hal-hal yang sensitif. Sikap Bambang yang seperti ini sebenarnya dilakukan untuk menghindari konflik dan hal-hal yang tidak diinginkan, Bambang tidak mau direpotkan dengan keteganganketegangan yang menurutnya tidak perlu. Akan tetapi hal ini membuat istrinya penasaran dengan jawaban Bambang, ketegangan ini sangat sering muncul ketika awal-awal pernikahan dan belum mengerti sifat satu dengan yang lain. Akibatnya Yati sebagai istri seringkali menanyakan pertanyaan yang sama berulang-ulang. Sikap Bambang yang tertutup menimbulkan kesalahpahaman yang terjadi diantara mereka dan pada akhirnya ketegangan muncul.

"Aku orangnya tertutup, tidak mudah bagiku untuk berkomunikasi dan mengatakan urusanku ke semuanya. Jadi itu mungkin yang menyebabkan salah paham."

Kutipan diatas menunjukkan bagaimana Bambang mengetahui bahwa penyebab dirinya sendiri yang tertutup membuat timbul kesalahpahaman saat berkomunikasi dengan orang lain bahkan istrinya. Permasalahan diawal pernikahan datang dari keluarga besar Yati yang menanyakan ketertarikan Bambang pada musik. Keluarga besar Yati sempat menanyakan hal tersebut tetapi jawaban yang sama juga didapatnya dari Bambang.

Sebenarnya alasan Bambang yang tidak menjawab pertanyaan karena dia merasa bahwa ini adalah urusan pribadinya dan menurut Bambang, orang lain tidak perlu mengetahui alasan dia bergabung dengan kelompok musik. Seperti pernyataan Bambang:

"Aku bosen selalu ditanya kenapa aku ikut disini. Bukannya aku gak mau jawab. Tapi gak semua orang mesti tau kan alasanku bergabung."

Dilihat dari pernyataan tersebut, sebenarnya Bambang ingin melindungi privasinya dengan tidak memberikan 
jawaban mengenai alasan dia bergabung. Sehingga ketidakterbukaan antara Bambang dan istrinya memunculkan ketegangan dalam hubungan mereka.

Ketegangan yang lainnya juga terjadi pada Helmi akibat etnis yang dia miliki. Penyebab dari ketegangan budaya yang terjadi adalah dari adanya stereotype akan etnis lainnya. Stereotip yaitu generalisasi (biasanya bersifat negative) atas sekelompok orang (suku, agama, ras) dengan mengabaikan perbedaanperbedaan individual. Di Indonesia, sering mendengar stereotip-stereotip kesukuan (Sihabudin, 2013 : 121). Stereotip mengenai sekelompok etnis inilah yang menimbulkan adanya kesalahpahaman yang menyebabkan ketegangan budaya. Stereotip akan etnis juga timbul sebagai penyebab munculnya ketegangan di keluarga besar Helmi dan istrinya.

Bagan IV.2. Bagan ketegangan yang terjadi pada pasangan suami istri Helmi dan Kiki

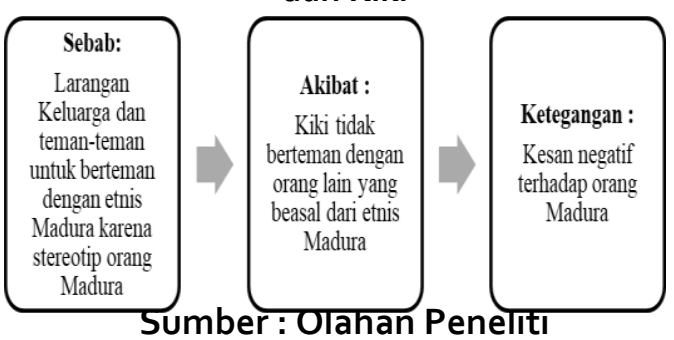

Seperti pernyataan Kiki,

"Dulu awal-awal kenal, pas aku ngajak ngomong Helmi, saudaraku ngomong, ngapain berhubungan sama dia. Dia loh Madura. Madura sama Jawa itu gak bisa temenan. Gak cuma saudaraku, ortu ku juga bilang gitu. Mereka bilang mending temenan sama yang Jawa aja daripada Madura yang keras, ngamuk'an ntar kamu jadi anak urak'an gimana. Sapa yang mau tanggung jawab. Emang keluarga Madura mau tanggung jawab? Kadang aku jengkel kan gak semua orang Madura gitu."
Pernyataan Kiki tersebut dapat menggambarkan jika keluarga Jawa memberikan pengaruh yang besar terhadap cara pertemanan Kiki dengan anggota etnis lain. Selain itu, campur tangan orangtua Kiki dalam menentukan siapa aja teman Kiki menimbulkan sebuah ketegangan. Keluarga Kiki yang memiliki etnis Jawa mengenal orang Madura sebagai orang yang memiliki temperamental yang tinggi, suka berkelahi, sikap yang keras, dan nakal. Stereotip mengenai etnis Madura yang ada dibenak orang tua Kiki membuat Kiki pada akhir memunculkan ketegangan antara Kiki dan Helmi yang beretnis Madura. Seperti pernyataan Kiki yang menirukan cara bicara orang tuanya :

"Ortuku itu takut kalo aku sama orang Madura. Mereka bilang kalo orang Madura itu keras, marahan, juga nakal. Jadi gak usah deketdeket. Gitu kata mereka. Jadi ya gitu sekarang gak temenan. Ortuku bilang dia udah pengalaman kalo menghadapi orang Madura. Jadi mereka tau betul bagaimana orang Madura itu."

Ketegangan terjadi karena perbedaan pendapat antara Kiki dengan teman-temannya dan keluarganya. Persepsi teman-teman dan keluarga Kiki mengenai orang Madura membuat mereka melarang Kiki untuk berteman dengan anggota lainnya yang berasal dari etnis lain. Ketakutan keluarga dan teman-teman Kiki memunculkan ketegangan dengan Kiki sendiri. Ketegangan yang terjadi pada Kiki adalah pandangan mengenai orang Madura menjadi pandangan yang nyata bagi beberapa orang. Sikap yang keras, kaku, temperamental, nakal dan suka dengan kekerasan merupakan pandangan masyarakat sekarang mengenai orang Madura. Karena pandangan inilah, teman dan keluarga Kiki pada awal hubungannya dengan Helmi dilarang untuk berteman 
bahkan menjalin hubungan romantic dengan orang yang beretnis Madura.

Idealnya, penampilan merupakan

kesan pertama ketika orang sedang berkenalan. Penampilan orang Madura yang tidak rapi cenderung membuat teman dan keluarga Kiki memberikan kesan negative terhadap orang Madura. Bagi orang tua Kiki penampilan yang rapi dan tutur bahasa yang halus yang dapat menjadi teman yang baik bagi Kiki.

Bagan IV.3. Bagan ketegangan yang terjadi pada pasangan suami istri Helmi dan Kiki

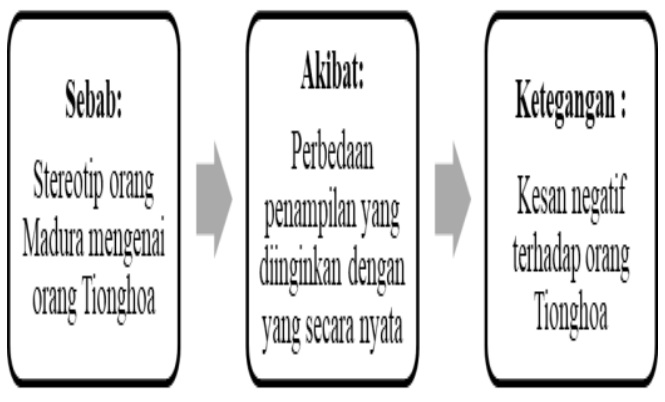

Sumber : Olahan Peneliti

Seperti stereotip orang Madura dimata orang Jawa, stereotip orang Jawa dimata orang Madura pun juga terbentuk, yaitu sombong, egois, dan seenaknya sendiri. Stereotip orang Jawa ini sudah melekat dibenak orang Madura. Ini juga yang membuat keluarga Helmi yang beretnis Madura juga berpikiran bahwa semua stereotipe negative tersebut juga dimiliki oleh Kiki yang beretnis Jawa. Seperti keluarga Helmi yang beretnis Madura yang menganggap bahwa semua etnis Jawa itu sombong dan seenaknya sendiri. Pernyataan tersebut di sampaikan oleh Helmi :

"Orang Jawa itu suka seenaknya sendiri. Semua yang dia mau harus dilakukan. Egois banget. Temenan aja juga gak mau. Males jadinya. Jadinya ya ngomong seperlunya aja. Dari ketemu awal uda kelihatan kalo mereka suka seenaknya sendiri."
Dilihat dari pernyataan diatas menunjukkan bahwa orang Madura telah melabeli orang Jawa dengan sifat yang egois dan sombong. Ternyata penyebab stereotip mengenai orang Jawa tidak hanya diketahui oleh satu anggota saja. Orang yang beretnis Madura lainnya juga hampir sama mengatakan mengenai stereotip orang Jawa.

"Aku dulu punya temen orang Jawa. Dari awal uda keliatan sombong. Uda gitu kalo disapa juga gak pernah bales. Jadinya aku temenan aja sama yang lain. Biasanya sih sama yang sama kayak aku. Biar enak juga kalo ngobrol. Biar gak keliatan sombong kayak yang sana."

Pernyataan yang sama dinyatakan

oleh Helmi yang beretnis Madura mengenai generalisasi sifat orang Jawa. Orang Jawa yang dianggap sombong karena tidak mau bertegur sapa dan karena sikapnya yang seenaknya membuat kesalahpahaman muncul diantara pemain musik. Stereotip ini merupakan stereotip etnis yang dianut oleh sebagian besar masyarakat suatu golongan etnis tentang beberapa sifat-sifat khas yang dapat mencirikan bagaimana suatu golongan tersebut.

Pernyataan dari beberapa informan diatas menunjukkan bahwa ketegangan terjadi pada hubungan individu, disebabkan oleh adanya perbedaan budaya membuat pasangan suami istri ini bersitegang satu sama lain diawal hubungan romantic yang mereka jalani. Ketegangan budaya yang dialami oleh pasangan suami istri ini tidak hanya disebabkan oleh komunikasi diantara hubungan mereka, tetapi juga ada factor dari luar hubungan yang membuat mereka mengalami ketegangan satu sama lain.

Seperti yang dikatakan oleh Baxter yang menyebut bahwa jenis ketegangan dapat dibagi menjadi dua yaitu ketegangan interactional dan ketegangan contextual. 
Ketegangan interactional sendiri masih mengandung beberapa ketegangan lagi yaitu otonomi dan keterikatan, keterbukaan dan perlindungan serta hal yang baru dan hal yang dapat diprediksi. Sedangkan di dalam ketegangan contextual ada ketegangan dialektika public dan privat serta dialektika yang nyata dan yang ideal (West \& Turner, 2009 : 238-241). Hasil wawancara yang dilakukan oleh peneliti dapat disimpulkan bahwa jenis-jenis ketegangan yang terdapat pada pasangan suami istri adalah ketegangan interactional karena keterbukaan dan perlindungan yang dialami oleh Bambang dan Yati istrinya.

Selain karena keterbukaan dan perlindungan, juga ada jenis ketegangan contextual juga terjadi pada pada pasangan suami istri Helmi dan Kiki. Seperti pada kasus Kiki yang dilarang berteman dengan anggota yang etnis Madura karena pengaruh keluarga dan temannya yang merupakan jenis ketegangan contextual karena dialektika public dan privat. Pada kasus Kiki juga dapat dimasukkan ke dalam jenis ketegangan contextual. Hal tersebut dikarenakan dialektika yang nyata dan ideal karena menunjukkan bagaimana hubungan yang ideal itu dengan bagaimana hubungan yang terjadi secara nyata dimana ada perbedaan antara hubungan yang ideal dengan hubungan yang terjadi secara nyata yang disebabkan oleh stereotip seseorang.

Ketegangan yang dipicu karena perbedaan sifat, kepribadian dan perilaku inilah yang membuat sebuah hubungan menjadi unik. Pernyataan tersebut diperkuat oleh pernyataan Sihabudin (2013 : 13) yang menyatakan Komunikasi antar budaya merupakan komunikasi yang terjadi antara orang-orang yang memiliki kebudayaan yang berbeda (ras, etnik, agama, atau sosio ekonomi). Hubungan yang memiliki anggota multikultural tentu saja harus memiliki beberapa cara agar komunikasi yang dilakukan oleh individu yang memiliki kebudayaan berbeda dapat terjalin dengan baik dan efektif.

Tabel IV.1. Ketegangan yang terjadi pada pasangan Suami Istri berbeda agama di Desa Balun, Lamongan.

\begin{tabular}{|c|c|c|c|}
\hline No. & $\begin{array}{c}\text { Pasangan } \\
\text { Suami } \\
\text { Istri }\end{array}$ & Kasus & $\begin{array}{c}\text { Ketegangan/ten } \\
\text { sion yang } \\
\text { terjadi }\end{array}$ \\
\hline 1. & $\begin{array}{c}\text { Bambang } \\
\text { dan Yati }\end{array}$ & $\begin{array}{c}\text { Bambang } \\
\text { dan } \\
\text { istrinya }\end{array}$ & $\begin{array}{c}\text { Bambang tidak } \\
\text { terbuka pada } \\
\text { latar belakang } \\
\text { dirinya ketika } \\
\text { ditanya oleh } \\
\text { keluarga besar } \\
\text { Yati (istrinya) }\end{array}$ \\
\hline 2. & $\begin{array}{c}\text { Helmi dan } \\
\text { Kiki }\end{array}$ & $\begin{array}{c}\text { Kiki } \\
\text { kepada } \\
\text { keluarga } \\
\text { Helmi }\end{array}$ & $\begin{array}{c}\text { Stereotipe } \\
\text { negatif etnis } \\
\text { Madura oleh } \\
\text { etnis Jawa }\end{array}$ \\
\hline 3. & $\begin{array}{c}\text { Helmi dan } \\
\text { Kiki }\end{array}$ & $\begin{array}{c}\text { kelmi } \\
\text { keluarga } \\
\text { Kiki }\end{array}$ & $\begin{array}{c}\text { Stereotipe } \\
\text { negatif etnis } \\
\text { Jawa oleh etnis } \\
\text { Madura }\end{array}$ \\
\hline
\end{tabular}

\section{Sumber : Olahan Peneliti}

Ketegangan-ketegangan yang terjadi pada pasangan suami istri berbeda agama di Desa Balun, harus segera dicari strategi apa yang digunakan agar tidak merusak hubungan. Maka dari itu, untuk meminimalisir ketegangan yang terjadi maka perlu adanya strategi untuk memanajemen ketegangan.

Sedangkan dalam kasus Bambang, dimana Bambang tidak terbuka ke istri dan keluarga besarnya membuat kesalahpahaman muncul. Pada kasus tersebut dibutuhkan strategi yang tepat agar ketegangan yang muncul karena kesalahpahaman tidak menjadi besar.

"Kan sudah tanya berkali-kali dan dia gak jawab jadi ya kita kalo ngomong sama dia ya gak mau bahas masalah 
itu lagi. Toh ntar ujung-ujungnya gak dijawab lagi. Jadi ya mendingan bahas topik lainnya yang bisa dia jawab."

Kutipan diatas disampaikan mengenai bagaimana strategi pasangan suami istri tersebut dalam meminimalkan ketegangan yang terjadi diantara mereka. Pada kasus tersebut, Bambang dan Kiki membuat kesepakatan untuk tidak membahas pertanyaan yang sangat dibenci oleh Bambang. Strategi ini digunakan oleh pasangan tersebut dalam berkomunikasi dimana dalam strategi ini mereka akan membahas topic pembicaraan lainnya dan tidak akan mendiskusikan lagi topic pembicaraan yang berkaitan dengan alasan Bambang memiliki ketertarikan khusus pada musik dan bergabung dalam kelompok musik gamelan. Strategi tersebut disebut sebagai Integration : Mendiskualifikasi.

\section{Bagan IV.4. Bagan penggunaan strategi untuk meminimalkan ketegangan Kasus Bambang dan Yati}

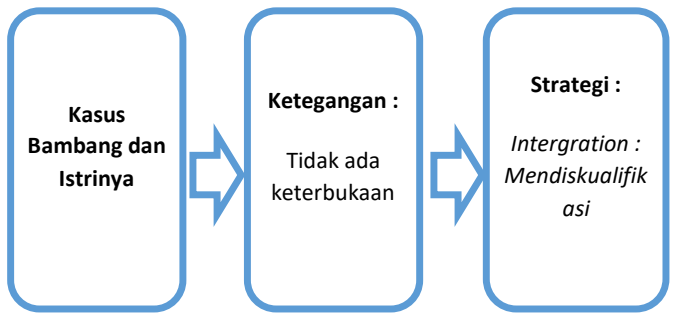

Sumber : Olahan Peneliti

Pada kasus ketegangan yang menyangkut Kiki, kesan negative dari orang tua dan saudara Kiki, membuatnya dilarang untuk berteman dan memiliki hubungan dengan pria yang berasal dari etnis Madura. Sehingga dibutuhkan strategi yang ampuh yang dapat digunakan untuk meminimalkan ketegangan yang terjadi. Seperti yang dikatakan oleh Kiki :

"Aku sempet bertengkar dengan ortuku masalah ini. Tapi sekarang masalah ini sudah selesai. Kesepakatan terjadi antara kami bahwa hubungan bisa dilanjutkan dengan memperhatikan dan wajib menjaga perasaan kelvarga kami masing-masing. Tidak bersikap egois, kasar, dan lain sebagainya. Harus bener-bener sadar pada sikap dan perkataan yang keluar."

Menurut Kiki, dengan adanya kesepakatan dengan Helmi dalam menjadi hubungan, Kiki sudah meminimalkan ketegangan yang terjadi karena stereotip orang Madura. Strategi untuk meminimalkan ketegangan tersebut disebut Selection, yaitu berhubungan dengan pembuatan keputusan dan keputusan diantara pertentangan yang terjadi.

\section{Bagan IV.5. Bagan penggunaan strategi untuk meminimalkan ketegangan Kasus Kiki terhadap keluarga Helmi}

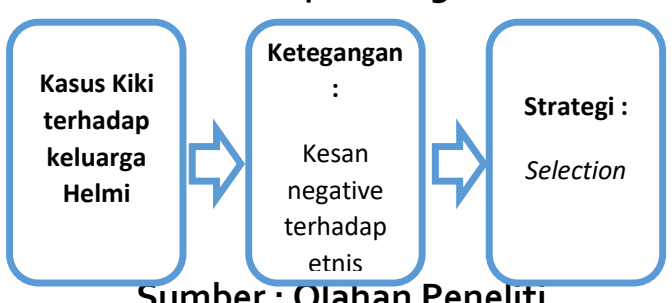

Sumber: Olahan Penelıtı

Sama halnya dengan kasus yang dialami oleh Kiki, mengenai stereotip orang Madura, strategi yang digunakan pun hampir sama dengan strategi yang digunakan oleh Helmi dimana antara etnis Jawa dan etnis Madura melakukan kesepakatan dalam hubungan mereka. Mereka memilih untuk menjalin hubungan dengan mengadakan kesepakatankesepakatan antara 2 belah pihak agar tetap terjalin hubungan yang baik, rukun dan harmonis. Strategi untuk meminimalkan ketegangan tersebut disebut Selection, yaitu berhubungan dengan pembuatan keputusan dan keputusan diantara pertentangan yang terjadi.

Bagan IV.4. Bagan penggunaan strategi untuk meminimalkan ketegangan Kasus Helmi terhadap keluarga Kiki

\begin{tabular}{|c|c|c|}
\hline \multirow{2}{*}{$\begin{array}{c}\text { Kasus Helmi } \\
\text { terhadap }\end{array}$} & Ketegangan : & \\
\hline keluarga Kiki & Kesan & Strategi : \\
\cline { 2 - 4 } & $\begin{array}{c}\text { negative } \\
\text { terhadap } \\
\text { etnis Jawa }\end{array}$ & Selection \\
\hline
\end{tabular}




\section{Sumber : Olahan Peneliti}

Beberapa strategi yang digunakan oleh pasangan suami istri di Desa Pancasila, Lamongan dalam meminimalkan ketegangan yang dikarenakan keragaman agama dapat ditemukan oleh peneliti. Strategi tersebut juga masih digunakan hingga saat ini untuk menunjang rasa saling menghargai dan saling menghormati.

Dapat disimpulkan bahwa mereka memiliki strategi untuk meminimalkan ketegangan yang terjadi diantara mereka. Agar ketegangan yang terjadi tidak merugikan sebuah hubungan suami istri dibutuhkan strategi untuk meminimalkan ketegangan. Ada beberapa strategi yang dapat digunakan untuk meminimalisir ketegangan, yaitu Cyclic alternation, Segmentation, Selection, dan Integration (West \& Turner, 2009). Hasil strategi yang digunakan oleh para pasangan suami istri ini yang didapat saat wawancara adalah dengan menggunakan strategi Selection dan Integration.

Pada kasus yang dialami oleh Bambang dan istrinya, mereka menggunakan strategi intergration dengan cara mendiskualifikasi. Cara ini digunakan untuk mendiskualifikasi pertanyaanpertanyaan yang akan memicu timbulnya ketegangan dengan membahas topic pembicaraan lainnya saat mereka berbicara satu sama lain.

Sedangkan pada kasus Kiki dan Helmi yang disebabkan oleh stereotip terhadap golongan etnis, menggunakan strategi Selection dimana strategi ini digunakan mereka untuk melakukan kesepakatan dalam hubungan mereka. Kesepakatan yang dibuatpun berhubungan dengan bagaimana hubungan yang terjalin diantara mereka terjadi di keluarga besar dengan diluar keluarga besar. Kesepakatan yang dibuat dengan tetap menjalin hubungan.

\section{Kesimpulan}

Dari pembahasan di atas dapat disimpulkan beberapa hal. Yang pertama terkait bentuk ketegangan yang terjadi pada pasangan beda agama di Desa Balun, Kecamatan Turi, Lamongan yaitu adanya ketidakterbukaan pada latar belakang pasangan yang berbeda agama, adanya Stereotipe negatif etnis Madura oleh etnis Jawa, dan juga sebaliknya. Akan tetapi ketegangan tersebut bisa diminimalkan dengan strategi yang dilakukan. Ditemukan bahwa Strategi Management Dialectical Tension Pasangan Suami-Istri Berbeda Agama di Desa Balun, Kecamatan Turi, Lamongan yang digunakan untuk Meminimalkan Ketegangan pada Keluarga berbeda-beda tergantung pada ketegangan/tension apa yang muncul. Ketegangan yang muncul pada dua pasangan suami istri tersebut adalah terkait tidak adanya keterbukaan dan stereotype terkait etnis yang berbeda.

Untuk ketegangan terkait tidak adanya keterbukaan dari suami, pasangan Bambang dan Yati menggunakan strategi Integration dengan cara mendiskualifikasi pertanyaan yang muncul, sehingga tidak ditanyakan dan tidak memicu ketegangan dalam hubungan suami istri tersebut. Sedangkan untuk ketegangan terkait stereotype etnis masing-masing keluarg pada pasangan Kiki dan Helmi, mereka menggunakan strategi yang sama yaitu Selection, dimana strategi ini digunakan mereka untuk melakukan kesepakatan dalam hubungan mereka. Kesepakatan yang dibuatpun berhubungan dengan bagaimana hubungan yang terjalin diantara mereka terjadi di keluarga besar dengan diluar keluarga besar. Kesepakatan 
yang dibuat dengan tetap menjalin hubungan.

\section{Referensi}

A. Supratiknya. 1995. Tinjauan Psikologi Komunikasi Antar Pribadi. Yogyakarta: Kanisius (Anggota IKAPI).

Anggorowati dan Sarmini. 2015. Pelaksanaan Gotong Royong di Era Global (Studi Kasus di Desa Balun Kecamatan Turi Kabupaten Lamongan). Kajian Moral dan Kewarganegaraan, (1)3.

Azizah, Kholis, Huda. 2020. Model Pluralisme Agama Berbasis Kearifan Lokal "Desa Pancasila" di Lamongan. Fikrah: Jurnal Ilmu Aqidah dan Studi, (8)1.

Baxter, Scharp. 2016. Dialectical Tensions in Relationships. John Wiley \& Sons, Inc. DOI:10.1002/9781118540190.wbeic 0017

Damayant. 2020. Kebijakan Kerukunan antar umat Beragama di Desa Balun, Kab. Lamongan. MADANI Jurnal Politik dan Sosial Kemasyarakatan, (12)1.

Devito, Joseph A. 2011. Komunikasi Antar Manusia. Pamulang-Tangerang Selatan: Karisma Publishing Group

Fiske, John. 2004. Cultural and Communication Studies: Sebuah Pengantar Paling Komprehensif. Yogyakarta: Jalasutra.

Husaini, Adian MA. 2005. Pluralisme Agama : Haram, Fatwa MUl yang Tegas dan Tidak Kontroversial. Jakarta: Pustaka Al Kausar.

Jonathan, Sarwono. 2006. Metode Penelitian Kuantitatif dan Kualitatif. Yogyakarta :Graha Ilmu Littlejohn, Stephen W. 1996. Theories of Human Communication-fifth edition. New Mexico: Wadsworth Publishing Company.

Martins, Pak, Martins. 2013. Communication and Leadership Dialectical Tensions in Virtual Communities of Practice. Journal for Theory and Practice Management. DOI: 10.7595/management.fon.2013.00 21

Muniruddin. 2019. Komunikasi Pengembangan Masyarakat Islam Analisis Teori Dialektika Relasional. Jurnal Pemberdayaan Masyarakat, 7(1), 66.

Purwasito. 2015. Komunikasi Multikultural. Yogyakarta : Pustaka Pelajar.

Putri \& Boer. 2019. Eksistensi Dinamika Dialektika Interpersonal Pada Relasi Antara Departemen Media dan Public Relations in Asgoc Media $18^{\text {th }}$ Asian Games Invitation Tournament. Mediakom : Jurnal Ilmu Komunikasi, 3(1), 73-74. https://doi.org.10.3576o/mkm.201 9.v3i1.1983

Rozi dan Utomo. 2019. Budaya Pluralisme dalam Penerimaan Masyarakat Desa Balun, Kabupaten Lamongan. Jurnal Ilmu Komunikasi Umsida, (8)1

Sihabudin, Ahmad. 2013. Komunikasi antarbudaya: Suatu perspektif multidimensi. Jakarta: Bumi Aksara.

Umam. 2020. Membangun Ketahanan Sosial Keluarga dalam Keberagaman. Welfare : Jurnal Ilmu Kesejahteraan Sosial, 9(1), 30-31.

Yin, Robert K. 2008. Studi Kasus (Desain Dan Metode). Jakarta : PT.Raja Grafindo Persada.

West, Richard and Lynn H. Turner. 2004. Introducing Communication Theory: Analysis and Application, 2nd. New York: Mc Graw - Hill 